\title{
Biogeochemistry of an afrotropical montane rain forest on Mt. Kilimanjaro, Tanzania
}

\author{
Marion Schrumpf*1, Wolfgang Zech*, Jan C. Axmacher $†$ and Herbert V. M. Lyaruuł
}

\author{
* Institute of Soil Science and Soil Geography, University of Bayreuth, Germany \\ $\dagger$ Institute of Biogeography, University of Bayreuth, Germany \\ $\ddagger$ Botany Department, University of Dar es Salaam, Tanzania \\ (Accepted 21 July 2005)
}

\begin{abstract}
In contrast to their well-studied counterparts in the Neotropics and in Asia, East African montane rain forests are surrounded by semi-arid savanna plains. These plains have a high erosion potential for salt crusts accumulated at the soil surface. Hence it may be hypothesized that East African montane forest ecosystems experience strongly enhanced nutrient inputs via dry deposition, which alters their overall biogeochemistry. The aim of our study was to test this hypothesis by investigating $\mathrm{K}, \mathrm{Mg}$, Ca, $\mathrm{Na}$ and $\mathrm{N}$-forms in rainfall, throughfall, fine litter, litter percolate and soil solution of a montane rain forest at Mt. Kilimanjaro. Four forest plots situated at elevations between 2250 and $2350 \mathrm{~m}$ asl on the south-western slopes of Mt. Kilimanjaro were studied for $2 \mathrm{y}$. In contradiction to our hypothesis, inputs of K, $\mathrm{Mg}$, Ca and Na via rainfall $\left(7.5,0.9,2.3\right.$ and $\left.6.2 \mathrm{~kg} \mathrm{ha}^{-1} \mathrm{y}^{-1}\right)$ and throughfall $\left(35,2.0,3.5\right.$ and $\left.11 \mathrm{~kg} \mathrm{ha}^{-1} \mathrm{y}^{-1}\right) \mathrm{were}^{2}$ low on Mt. Kilimanjaro. Fluxes of $\mathrm{NH}_{4}-\mathrm{N}$ and $\mathrm{NO}_{3}-\mathrm{N}$ were within the range observed at other montane rain forests, with $\mathrm{NO}_{3}-\mathrm{N}$ being the only nutrient partly absorbed in the forest canopies $\left(2.9 \mathrm{~kg} \mathrm{ha}^{-1} \mathrm{y}^{-1}\right.$ in rainfall, $0.9 \mathrm{~kg} \mathrm{ha}^{-1} \mathrm{y}^{-1}$ in throughfall). The highest overall nutrient concentrations in water samples occurred in litter percolate $\left(1.4 \mathrm{mg}^{-1} \mathrm{~K}_{\text {, }}\right.$ $0.3 \mathrm{mg} \mathrm{l}^{-1} \mathrm{Mg}, 0.8 \mathrm{mg} \mathrm{l}^{-1} \mathrm{Ca}, 0.3 \mathrm{mg} \mathrm{l}^{-1} \mathrm{NH}_{4}-\mathrm{N}, 0.9 \mathrm{mg} \mathrm{l}^{-1} \mathrm{NO}_{3}-\mathrm{N}$ ), with values still being low compared to other sites. Nutrient concentrations in seepage water strongly declined with increasing soil depth. Thus, both inputs and losses of base cations from the forest by water pathways are assumed to be low. $\mathrm{N}$ or $\mathrm{P}$ limitation of growth is not expected since high fluxes of $\mathrm{N}$ and $\mathrm{P}$ in fine litter (119 and $5.9 \mathrm{~kg} \mathrm{ha}^{-1} \mathrm{y}^{-1}$ for $\mathrm{N}$ and $\mathrm{P}$ respectively) indicate low within-stand efficiency.
\end{abstract}

Key Words: litter, montane rain forest, Mount Kilimanjaro, nutrient cycling, rainfall, soil solution, Tanzania, throughfall

\section{INTRODUCTION}

Tropical montane rain forests have received increasing scientific attention during the past decades due to their high biodiversity (Myers et al. 2000) and their value as water catchment areas (Bruijnzeel 2001, 2004). Most studies on biogeochemical cycling in montane rain forests have focused on South and Central America and Asia, where these forests cover large areas (Bubb et al. 2004).

In East Africa, montane rain forests only cover small areas. In Tanzania for example, less than $2 \%$ of the total area is covered by moist forests (Bjørndalen 1992). Nevertheless, they are of great ecological and economic

\footnotetext{
${ }^{1}$ Corresponding author. Present address: Max-Planck-Institute for Biogeochemistry, PO Box 100164, D-07701 Jena, Germany. Email: mschrumpf@bgc-jena.mpg.de
}

value as they form isolated humid ecosystems providing water for regional agricultural production and hydroelectric power stations (Sarmett \& Faraji 1991). Rainforests on isolated mountains, like on Mt. Kilimanjaro, are surrounded by semi-arid savanna plains. These tend to accumulate salt crusts at the soil surface and are at the same time strongly affected by wind erosion (Prospero 1999). Therefore, deposition of salts on the canopy of East African montane rain forests is potentially higher compared to montane rain forests growing in more humid regions, which potentially affects the whole nutrient cycle of these ecosystems.

Data on the nutrient status of montane rain forests in East Africa are extremely scarce. Above- and belowground biomass, litterfall, rainfall and soil properties in natural forests and forest plantations on Mt. Meru and in the Usambara Mts., Tanzania, were studied by Lundgren (1978) and Lundgren \& Lundgren (1979). 
On Mt. Kilimanjaro, possible effects of the conversion of natural forests to forest plantations on major soil properties and changes in the run-off regime have so far only been analysed in the cultivated zone below the montane rain forests (Iseki et al. 1981, Maro et al. 1991, Mizota et al. 1988, Sarmett \& Faraji 1991).

In our study, we wanted to investigate whether different aspects of the biogeochemistry of East African montane rain forests differ from montane rain forests elsewhere. In order to explore this question, a mature montane rain forest on the south-western slopes of Mt. Kilimanjaro, Tanzania was chosen as an example. In addition to concentrations and fluxes of main nutrients in rainfall, throughfall and litterfall, we analysed nutrient concentrations in the forest floor percolate, the soil solution and stream water. For our analysis, we were particularly interested in the following three questions:

(1) Due to the isolation of the humid afrotropical montane rain forests in a salt-affected semi-arid savanna environment, the forest ecosystems potentially experience high intakes of nutrients via wet and dry deposition from the surrounding savanna. Is this effect visible in nutrient fluxes via rainfall and throughfall?

(2) Are the assumed high nutrient inputs reflected in high nutrient concentrations in below-ground seepage water, or are nutrients widely retained within the forest ecosystem?

(3) $\mathrm{N}$ or $\mathrm{P}$ might be limiting factors in the tropical montane rain forest of Mt. Kilimanjaro due to low mineralization rates and a high $P$ fixation capacity of volcanic soils. Is this evident from litter analyses?

\section{METHODS}

\section{Study area}

The study was conducted on the humid south-western slopes of Mt. Kilimanjaro above Machame village. At an altitudinal range between 2250 and $2350 \mathrm{~m}$, four plots of old-growth forest with intact closed canopy were selected $\left(3^{\circ} 8^{\prime} \mathrm{S}, 37^{\circ} 14^{\prime} \mathrm{E}\right)$.

According to Hemp (2002), the mature forest in the study area can be classified as middle montane OcoteaPodocarpus forest dominated by Ocotea usambarensis Engl. trees in association with Podocarpus latifolius R. Br. Similarly, Lovett \& Urono (1994) classified the forest at Mt. Kilimanjaro between 1600 and $2700 \mathrm{~m}$ as montane forest, and the area above $2400-2500 \mathrm{~m}$ as upper montane forest. The canopy reaches heights of $40 \mathrm{~m}$, and the forest is characterized by a high density of epiphytes (Hemp et al. 1999), with lower portions of tree stems usually completely coated by an epiphytic layer. This layer mainly consists of bryophytes and reaches a thickness of more than $10 \mathrm{~cm}$. A large number of pteridophytes are also contained within the epiphytic layers. The hydrological importance of the diversity and total biomass of lower plants in the forest of Mt. Kilimanjaro was emphasized by Pócs (1991). Lists of vascular plant species on the plots are presented in Axmacher (2003).

The Kilimanjaro region experiences a bimodal rainfall distribution with rainy seasons lasting from March to June and from November to December. For the most humid southern slopes of the mountain at $2200 \mathrm{~m}$, Røhr \& Killingtveit (2003) reported a rainfall maximum of more than $3500 \mathrm{~mm}$. Temperature measurements carried out in the study area on 50 days from May to October and hence covering both parts of the main rainy season and the long dry season revealed a median daily minimum temperature of $8.7^{\circ} \mathrm{C}$ and a maximum of $14.8^{\circ} \mathrm{C}$. The soils in the study area have developed in volcanic ash layers of different age deposited on lavas of the Lent Group (phonolites and trachyandesites; Downie \& Wilkinson 1972).

\section{Study design}

The study was conducted on four plots of $400 \mathrm{~m}^{2}$ each. The minimum distance between neighbouring plots was $130 \mathrm{~m}$, the maximum distance $340 \mathrm{~m}$. In order to avoid a strong influence of erosion, surface run-off and subsurface lateral flows, all plots had an inclination of less than $10^{\circ}$. A soil profile was established in the vicinity of each plot to a maximum depth of $2.3 \mathrm{~m}$ in order to assess main soil properties. Samples were taken by horizon from three sides of the pit walls for laboratory analyses. Homogeneity of soils on the plots was verified by soil coring. Litter was collected from the organic soil layers separately for the L, Oi and Oa horizons at five locations per plot.

For throughfall measurement, all plots were equipped with 8-10 randomly distributed collectors consisting of a sharp-rimmed funnel (115-mm diameter) and a 2-1 collecting bottle (polyethylene). The lower $100 \mathrm{~mm}$ of the collectors were buried in the ground so that the funnel rim was about $350 \mathrm{~mm}$ above the ground. The funnel outlet was covered by a 1-mm plastic mesh to avoid contamination of the samples by litter, and a table-tennis ball was placed in the funnel to reduce evaporation. If necessary, the funnel was cleaned after each sampling, whereas all collecting bottles were cleaned at least twice a year using a brush and deionized water. In a nearby forest gap, five raincatchers of similar construction were installed $1.5 \mathrm{~m}$ above the ground for rainfall sampling.

Four free-draining litter percolate collectors were installed below the dense root mat in the Oa horizon of the litter layer at each plot. These consisted of square plastic boxes with a side length of $285 \mathrm{~mm}$ and a height of $80 \mathrm{~mm}$. Each box was covered with a 1-mm mesh net and 
connected via a silicon tube to a polyethylene sampling bottle. Suction cups (SKL100, ceramic cup K100, UMS, Munich) for soil water extraction were installed at soil depths of $0.15,0.30$ and $1.00 \mathrm{~m}$ in three replicates per plot. Cups from different depths were grouped in a triangle with $1 \mathrm{~m}$ side length, with three triangles situated in a larger triangle with a distance of $5 \mathrm{~m}$ to a pump (Vacuum case VK-3, UMS, Munich) located at the plot centre. Suction cups were installed in holes created by a soil corer with a similar diameter as the suction cups. As the hole diameter increased by several $\mathrm{mm}$ at the uppermost part during the extraction of the corer, the immediate surroundings of the suction cups were filled with suspended soil material of the corresponding soil horizon to prevent preferential flow along the sampler tube and to ensure direct contact with the soil. The shaft was further sealed with a silicon ring (0.1-m diameter) at the soil surface. One day before sampling, the pumps were started to create a constant suction of $400 \mathrm{hPa}$ for $24 \mathrm{~h}$. On each plot, samples of equal soil depth were combined in one Duran glass bottle. Stream water samples were collected regularly using polyethylene bottles submersed in a small catchment at $2220 \mathrm{~m}$ elevation, some $400 \mathrm{~m}$ away from the study plots in mature forest.

Square litter collectors with $0.5 \mathrm{~m}$ side length covered with a polyethylene net (1-mm mesh) were placed horizontally $0.25 \mathrm{~m}$ above the ground on three plots in two replicates each in order to estimate litterfall.

\section{Sampling procedure and sample treatment}

All samples collected during the first 2 mo were discarded to avoid effects caused by the installation of the equipment. Starting from May 2000, water samples from raincatchers, throughfall gauges, litter percolate collectors and suction cups were sampled twice a week (alternating every 3 and $4 \mathrm{~d}$ ). Installation of the litter percolate collectors was only completed in October 2000, so that the respective data are lacking for the first $5 \mathrm{mo}$. Whilst water volumes were reported separately for each rain and litter percolate collector, volume-weighted composite samples representing the whole plot were taken in the field. Later on, water samples from individual sampling dates were combined to composite samples of 14-d periods and stored frozen. Samples of rain and litter percolate were mixed volume-weighted, while equal portions were used for the soil solution samples as no reliable information about the below-ground water fluxes was available. On three sampling occasions, samples had to be excluded from mixed samples as either data on volume or samples were missing. Suction cups extracted soil water regularly except for dry periods mainly in September and October. Whenever no soil solution was available for individual times and soil depths, mixed samples were made of the remaining samples of the 14-d period. From May 2001 onwards, sampling frequency was reduced to weekly collections.

Litterfall samples were taken on a monthly basis starting from November 2000. Litter samples were also combined for each plot and stored after air-drying.

\section{Chemical analyses}

Analyses of the mineral soil were carried out on airdried samples $\left(40^{\circ} \mathrm{C}\right)$ of the fraction $<2 \mathrm{~mm}$. $\mathrm{pH}$ was determined using $\mathrm{H}_{2} \mathrm{O}$ and $0.01 \mathrm{M} \mathrm{CaCl}_{2}$ at a soil : solution ratio of $1(\mathrm{~m}): 2.5(\mathrm{v})$ with a standard combined electrode with integrated temperature probe (WTW SenTix $41 \mathrm{pH}$ 330). Total carbon $\left(\mathrm{C}_{\mathrm{t}}\right)$ and nitrogen $\left(\mathrm{N}_{\mathrm{t}}\right)$ contents were analysed on ball-milled samples using a total element analyser (Elementar Vario EL). Exchangeable cations $(\mathrm{K}, \mathrm{Ca}, \mathrm{Mg}, \mathrm{Na}, \mathrm{Al})$ were extracted by a $0.5 \mathrm{M} \mathrm{NH}_{4} \mathrm{Cl}$ solution (Trüby \& Aldinger 1989) and measured by atomic absorption (Varian SpectrAA 400). The ECEC was calculated as the sum of the exchangeable base cations and exchangeable Al. Dissolution of $\mathrm{Al}$ was tested in a $0.2 \mathrm{M}$ oxalate solution at $\mathrm{pH} 3$ (Schwertmann 1964) to get $\mathrm{Al}$ bound in metal-humus complexes, allophane, imogolite and ferrihydrite $\left(\mathrm{Al}_{\mathrm{O}}\right)$. $\mathrm{Al}$ in extracts was measured by atomic absorption. Particle size distributions were analysed using field moist samples, which were stored at temperatures around $4{ }^{\circ} \mathrm{C}$. Soil samples were dispersed by shaking $5 \mathrm{~g}$ of soil in $20 \mathrm{ml} 0.1 \mathrm{M} \mathrm{Na}_{4} \mathrm{P}_{2} \mathrm{O}_{7}$ solution added to $500 \mathrm{ml}$ water overnight. Sand-size particles were removed by sieving, silt and clay contents were determined using the pipette method (Gee \& Bauder 1986). The $P$ retention capacity was measured in only one soil profile following the method of Burt (1996).

Rainfall, throughfall and litter percolate solutions were filtered through ash-free filter paper with a pore size $<2 \mu \mathrm{m}$ prior to analyses (Schleicher \& Schuell, blue band $589^{3}$ ). Therefore, overall solute concentrations were probably slightly overestimated since not only dissolved elements $(<0.45 \mu \mathrm{m})$, but also elements in particles $<2 \mu \mathrm{m}$ were involved in chemical analyses. Litter samples from the soil litter layer as well as from the litter collectors were oven-dried in the laboratory $\left(70{ }^{\circ} \mathrm{C}\right)$, ground, and digested with concentrated $\mathrm{HNO}_{3}$ under pressure for nutrient analysis (after Heinrichs et al. 1986). Determination of total N and S concentrations was conducted on ball-milled samples using a total element analyser (Elementar Vario EL). Flame absorption spectrometry (AAS; Varian SpectrAA 400) was used to measure element concentrations of $\mathrm{K}, \mathrm{Mg}, \mathrm{Ca}$ and $\mathrm{Na}$ in water samples and plant extracts. $\mathrm{NO}_{3}-\mathrm{N}$ and $\mathrm{NH}_{4}-\mathrm{N}$ in rain and soil solution samples were analysed with a Segmented Flow Analyser (SAN plus SYSTEM, SKALAR), as were the $\mathrm{P}$ concentrations in plant extracts. For one 
Table 1. Selected soil properties (mean \pm SE, $\mathrm{n}=4$, texture: $\mathrm{n}=3$ ) of four soil profiles in the montane rain forest on Mt. Kilimanjaro at three different soil depths (0.1-0.2, 0.25-0.35 and 0.95-1.05 m, representing depths of suction for soil water sampling) and in the Oa organic soil layer.

\begin{tabular}{|c|c|c|c|c|c|}
\hline & & \multirow[b]{2}{*}{ Oa } & \multicolumn{3}{|c|}{ Soil depth (m) } \\
\hline & & & $0.10-0.20$ & $0.25-0.35$ & $0.95-1.05$ \\
\hline $\mathrm{pH}\left(\mathrm{H}_{2} \mathrm{O}\right)$ & & $3.8 \pm 0.3$ & $4.0 \pm 0.1$ & $4.6 \pm 0.1$ & $4.7 \pm 0.1$ \\
\hline $\mathrm{pH}(\mathrm{KCl})$ & & $3.1 \pm 0.2$ & $3.3 \pm 0.1$ & $4.3 \pm 0.1$ & $5.0 \pm 0.1$ \\
\hline $\mathrm{C}$ & $\left(\mathrm{g} \mathrm{kg}^{-1}\right)$ & $369 \pm 19$ & $188 \pm 28$ & $117 \pm 12$ & $70 \pm 7$ \\
\hline $\mathrm{N}$ & $\left(\mathrm{g} \mathrm{kg}^{-1}\right)$ & $26 \pm 1$ & $11 \pm 2$ & $6.2 \pm 0.4$ & $3.0 \pm 0.5$ \\
\hline Clay & $\left(\mathrm{g} \mathrm{kg}^{-1}\right)$ & & $747 \pm 71$ & $634 \pm 126$ & $494 \pm 70$ \\
\hline Alo* & $\left(\mathrm{g} \mathrm{kg}^{-1}\right)$ & & $9.3 \pm 2.2$ & $37.4 \pm 5.5$ & $57.5 \pm 6.8$ \\
\hline ECEC* & $\left(\mathrm{cmol}(+) \mathrm{kg}^{-1}\right)$ & $16 \pm 1.7$ & $3.0 \pm 0.4$ & $0.7 \pm 0.9$ & $0.6 \pm 0.2$ \\
\hline K & $\left(\mathrm{cmol}(+) \mathrm{kg}^{-1}\right)$ & $0.78 \pm 0.15$ & $0.23 \pm 0.04$ & $0.06 \pm 0.01$ & $0.06 \pm 0.02$ \\
\hline $\mathrm{Mg}$ & $\left(\mathrm{cmol}(+) \mathrm{kg}^{-1}\right)$ & $2.58 \pm 0.65$ & $0.24 \pm 0.03$ & $0.03 \pm 0.01$ & $0.01 \pm 0.01$ \\
\hline $\mathrm{Ca}$ & $\left(\mathrm{cmol}(+) \mathrm{kg}^{-1}\right)$ & $4.96 \pm 1.51$ & $0.40 \pm 0.04$ & $0.10 \pm 0.02$ & $0.19 \pm 0.17$ \\
\hline $\mathrm{Na}$ & $\left(\mathrm{cmol}(+) \mathrm{kg}^{-1}\right)$ & $0.28 \pm 0.06$ & $0.09 \pm 0.02$ & $0.05 \pm 0.02$ & $0.03 \pm 0.01$ \\
\hline $\mathrm{Al}$ & $\left(\mathrm{cmol}(+) \mathrm{kg}^{-1}\right)$ & $6.15 \pm 0.81$ & $1.13 \pm 0.18$ & $0.38 \pm 0.03$ & $0.32 \pm 0.07$ \\
\hline
\end{tabular}

${ }^{*} \mathrm{Al}_{\mathrm{o}}$ : acid oxalate extractable $\mathrm{Al}$; ECEC: effective cation exchange capacity.

year, $\mathrm{Cl}$ concentrations were analysed in rainfall samples using an ion chromatograph.

\section{Data analysis and statistical evaluation}

Plots were monitored for a total of $2 \mathrm{y}$ from June 2000 to June 2002. Since no reliable data on soil water fluxes were available, the median nutrient concentration of 14-d samples was used as annual mean for the soil solution, while volume-weighted means were calculated for nutrient concentrations in rainfall and throughfall. The annual mean for litter percolate was volumeweighted according to throughfall fluxes, assuming that water uptake by roots was comparable among sites. Nutrient fluxes in rainfall and throughfall were calculated by multiplying recorded water fluxes with the respective element concentrations. Net throughfall fluxes were determined as the difference between throughfall and rainfall fluxes. Nutrient fluxes for litter percolate and soil solution could not be determined since no reliable information on water fluxes was available because of a lack of climate and runoff data.

Conservative estimates of stemflow fluxes from measurements on one Podocarpus latifolius and three Ocotea usambarensis trees over $1 \mathrm{y}$ proved that it contributes less than $1 \%$ to rainfall amounts. Tree stems were surrounded by a pipeline of foam rubber, which was connected to 50-l plastic containers via plastic tubes. Median concentrations for $\mathrm{K}, \mathrm{Mg}$, Ca and Na were 8.2, 0.46, 1.74 and $0.63 \mathrm{mg} \mathrm{l}^{-1}$ respectively for P. latifolius and $4.48 \pm 0.78$, $0.17 \pm 0.04,0.37 \pm 0.05$ and $0.86 \pm 0.10 \mathrm{mg} \mathrm{l}^{-1}$ respectively for $O$. usambarensis. Thus, although enriched in nutrients, stemflow was not considered to be of great relevance for total nutrient fluxes in the forest. Since there were continual problems with blockage of the collection channel around the tree and a lot of water bypassed the channel by dropping from the thick moss layers above the collector, stemflow fluxes were not always accurately determined and measurements were abandoned in the second study year. Hence, results of nutrients fluxes in stemflow are not considered further in this paper.

Statistical analyses were conducted using STATISTICA 5.0 (Statsoft, Inc., Tulsa, OK). Correlation analyses were done as Pearson Product-Moment Correlations.

\section{RESULTS}

\section{Soil properties}

The soils in the study area were classified as Placaquands and Fulvudands (Soil Survey Staff 2003, http://soils. usda.gov/technical/classification/tax keys/). Overall soils were characterized by low $\mathrm{pH}$ values, high concentrations of $\mathrm{C}$ and $\mathrm{N}$ and high clay contents with huge amounts of non-crystalline Al oxides and hydroxides (Table 1). Mean carbon and nitrogen stocks were high and accounted for 164 and $10 \mathrm{tha}^{-1}$ respectively in the organic soil horizons and for 565 and $26 \mathrm{tha}^{-1}$ in the mineral soil. The $\mathrm{P}$ retention capacity was measured in only one soil profile where it varied between 96 and $100 \%$. Due to low $\mathrm{pH}$ values, corresponding low effective cation exchange capacity and base saturation, periodic water stagnation and a high P fixation capacity of the soils, the available pool for most nutrients was relatively poor. Highest amounts of exchangeable nutrient cations were detected in the organic soil horizons (Table 1). Total concentrations of nutrients in the Oi litter layer were $16.2 \mathrm{~g} \mathrm{~kg}^{-1}$ for $\mathrm{N}, 1.1 \mathrm{~g} \mathrm{~kg}^{-1}$ for $\mathrm{P}, 1.5 \mathrm{~g} \mathrm{~kg}^{-1}$ for $\mathrm{K}, 1.9 \mathrm{~g} \mathrm{~kg}^{-1}$ for $\mathrm{Mg}$, $12.6 \mathrm{~g} \mathrm{~kg}^{-1}$ for $\mathrm{Ca}$ and $0.36 \mathrm{~g} \mathrm{~kg}^{-1}$ for $\mathrm{Na}$. The $\mathrm{C} / \mathrm{N}$ ratio was 30 .

\section{Rainfall and throughfall amounts}

Between June 2000 and June 2002, rainfall amounts were $2480 \mathrm{~mm}$ in the first and $1960 \mathrm{~mm}$ in the second, 
Table 2. Annual means of nutrient concentrations $\left(\mathrm{mg} \mathrm{l}^{-1}\right)$ in different ecosystem compartments of a montane rain forest at Mt. Kilimanjaro $( \pm \mathrm{SE}$, $\mathrm{n}=4$ ). For rainwater and throughfall, volume-weighted mean concentrations for each year (1 and 2 from June 2000 until May 2002) were calculated, while the median concentration was used for litter leachates, soil solution and stream water.

\begin{tabular}{|c|c|c|c|c|c|c|c|}
\hline & Year & $\mathrm{K}$ & $\mathrm{Mg}$ & $\mathrm{Ca}$ & $\mathrm{Na}$ & $\mathrm{NH}_{4}-\mathrm{N}$ & $\mathrm{NO}_{3}-\mathrm{N}$ \\
\hline \multirow[t]{2}{*}{ Rainfall } & 1 & 0.30 & 0.04 & 0.09 & 0.30 & 0.16 & 0.13 \\
\hline & 2 & 0.50 & 0.05 & 0.15 & 0.36 & 0.16 & 0.17 \\
\hline \multirow[t]{2}{*}{ Throughfall } & 1 & $1.50 \pm 0.20$ & $0.08 \pm 0.02$ & $0.13 \pm 0.01$ & $0.53 \pm 0.09$ & $0.19 \pm 0.02$ & $0.05 \pm 0.01$ \\
\hline & 2 & $2.97 \pm 0.15$ & $0.16 \pm 0.03$ & $0.34 \pm 0.05$ & $0.90 \pm 0.11$ & $0.19 \pm 0.01$ & $0.05 \pm 0.01$ \\
\hline \multirow[t]{2}{*}{ Litter percolate } & 1 & - & - & - & - & - & - \\
\hline & 2 & $1.63 \pm 0.36$ & $0.32 \pm 0.06$ & $0.89 \pm 0.18$ & $0.87 \pm 0.04$ & $0.30 \pm 0.04$ & $0.89 \pm 0.13$ \\
\hline \multicolumn{8}{|l|}{ Soil solution } \\
\hline \multirow[t]{2}{*}{$0.15 \mathrm{~m}$} & 1 & $0.15 \pm 0.04$ & $0.15 \pm 0.06$ & $0.27 \pm 0.10$ & $0.42 \pm 0.07$ & $0.03 \pm 0.00$ & $1.48 \pm 0.34$ \\
\hline & 2 & $0.19 \pm 0.04$ & $0.11 \pm 0.02$ & $0.25 \pm 0.06$ & $0.41 \pm 0.08$ & $0.04 \pm 0.00$ & $1.54 \pm 0.55$ \\
\hline \multirow[t]{2}{*}{$0.30 \mathrm{~m}$} & 1 & $0.16 \pm 0.04$ & $0.14 \pm 0.06$ & $0.25 \pm 0.08$ & $0.35 \pm 0.07$ & $0.02 \pm 0.00$ & $1.42 \pm 0.13$ \\
\hline & 2 & $0.18 \pm 0.03$ & $0.15 \pm 0.06$ & $0.26 \pm 0.08$ & $0.38 \pm 0.09$ & $0.04 \pm 0.00$ & $1.41 \pm 0.31$ \\
\hline \multirow[t]{2}{*}{$1.00 \mathrm{~m}$} & 1 & $0.15 \pm 0.02$ & $0.13 \pm 0.02$ & $0.21 \pm 0.06$ & $0.31 \pm 0.03$ & $0.03 \pm 0.00$ & $1.11 \pm 0.12$ \\
\hline & 2 & $0.21 \pm 0.04$ & $0.13 \pm 0.03$ & $0.27 \pm 0.08$ & $0.40 \pm 0.05$ & $0.04 \pm 0.00$ & $1.07 \pm 0.17$ \\
\hline \multirow[t]{2}{*}{ Stream } & 1 & 0.70 & 0.07 & 0.14 & 1.18 & 0.05 & 0.60 \\
\hline & 2 & 0.84 & 0.08 & 0.16 & 1.25 & 0.06 & 0.56 \\
\hline
\end{tabular}

Table 3. Mean nutrient fluxes $\left(\mathrm{kg} \mathrm{ha}^{-1} \mathrm{y}^{-1}\right)$ via rainfall and throughfall in a montane rain forest on Mt. Kilimanjaro, Tanzania. Net fluxes were calculated as difference between throughfall and rainfall fluxes $( \pm \mathrm{SE}, \mathrm{n}=4)$.

\begin{tabular}{lcllllll}
\hline & Year & \multicolumn{1}{c}{$\mathrm{K}$} & $\mathrm{Mg}$ & $\mathrm{Ca}$ & $\mathrm{Na}$ & $\mathrm{NH}_{4}-\mathrm{N}$ & $\mathrm{NO}_{3}-\mathrm{N}$ \\
\hline Rainfall & 1 & 6.9 & 0.9 & 2.1 & 6.7 & 3.6 & 3.0 \\
& 2 & 8.0 & 0.8 & 2.4 & 5.7 & 2.5 & 2.7 \\
Throughfall & 1 & $32.2 \pm 4.0$ & $1.8 \pm 0.4$ & $2.8 \pm 0.3$ & $11.5 \pm 2.0$ & $4.2 \pm 0.4$ & $1.0 \pm 0.3$ \\
& 2 & $37.2 \pm 1.8$ & $2.0 \pm 0.3$ & $4.2 \pm 0.6$ & $11.2 \pm 1.2$ & $2.4 \pm 0.1$ & $0.7 \pm 0.2$ \\
\multirow{2}{*}{ Net throughfall } & 1 & 25.3 & 0.9 & 0.7 & 4.8 & 0.6 & -2 \\
& 2 & 29.2 & 1.2 & 1.8 & 5.5 & -0.1 & -2 \\
\hline
\end{tabular}

drier year. Annual throughfall amounts reached 2040 and $1370 \mathrm{~mm}$, respectively, resulting in a total rainfall interception (rainfall-throughfall) of $18 \%$ in the first and $30 \%$ in the second year. Standard deviations for collected water amounts in individual throughfall collectors within one plot were usually in the range $10-20 \%$ of the mean. This error was not included in the standard errors presented for the means among sites in Tables 2 and 3.

\section{Water chemistry in ecosystem compartments}

Concentrations and fluxes of nutrients in rainfall were highest for $\mathrm{K}$ and decreased in the order $\mathrm{K}>\mathrm{Na}>$ $\mathrm{NH}_{4}-\mathrm{N}, \mathrm{NO}_{3}-\mathrm{N}>\mathrm{Ca}>\mathrm{Mg}$ (Tables 2 and 3). Annual mean $\mathrm{Cl}$ concentrations in rainfall were $0.86 \mathrm{mgl}^{-1}$. Annual mean concentrations of all base cations were higher in throughfall than in rainfall, except for $\mathrm{NO}_{3}-\mathrm{N}$, where throughfall concentrations were lower. Thus, although total water fluxes declined, net fluxes of all basic cations were positive, indicating a net enrichment of these ions during their passage through the canopy $\left(27 \mathrm{~kg} \mathrm{ha}^{-1} \mathrm{y}^{-1} \mathrm{~K}, 1.1 \mathrm{~kg} \mathrm{ha}^{-1} \mathrm{y}^{-1} \mathrm{Mg}, 1.3 \mathrm{~kg} \mathrm{ha}^{-1} \mathrm{y}^{-1}\right.$ $\mathrm{Ca}, 5.2 \mathrm{~kg} \mathrm{ha}^{-1} \mathrm{y}^{-1} \mathrm{Na}$ ). The highest enrichment rates (throughfall fluxes divided by rainfall fluxes) were obtained for $\mathrm{K}$ (5), followed by $\mathrm{Mg}(2.4)>\mathrm{Na}$ (1.8) $>\mathrm{Ca}(1.6) . \mathrm{NH}_{4}-\mathrm{N}$ showed net fluxes close to zero $\left(0.3 \mathrm{~kg} \mathrm{ha}^{-1} \mathrm{y}^{-1}\right)$ while negative net fluxes of $\mathrm{NO}_{3}-\mathrm{N}$ $\left(-2 \mathrm{~kg} \mathrm{ha}^{-1} \mathrm{y}^{-1}\right)$ indicated a net retention in the forest canopy for both years.

In litter percolate, concentrations exceeded throughfall values for all nutrients except $\mathrm{K}$ and $\mathrm{Na}$ (Figure 1, Table 2). The greatest increase was observed for $\mathrm{NO}_{3}-\mathrm{N}$ $\left(0.1 \mathrm{mg} \mathrm{l}^{-1}\right.$ in throughfall and $0.9 \mathrm{mg} \mathrm{l}^{-1}$ in litter percolate). In the soil solution, all concentrations with the exception of $\mathrm{NO}_{3}-\mathrm{N}$ were distinctly lower than in the litter percolate (Figure 1, Table 2). Overall concentrations in the soil solution decreased in the order $\mathrm{NO}_{3}-\mathrm{N}>\mathrm{Na}>$ $\mathrm{Ca}>\mathrm{K}, \mathrm{Mg}>\mathrm{NH}_{4}-\mathrm{N}$. Cation concentrations in the soil solution were generally very low (K: $0.15-0.21 \mathrm{mg} \mathrm{l}^{-1}$, Mg: 0.11-0.15 $\mathrm{mg} \mathrm{l}^{-1}$, Ca: $0.21-0.27 \mathrm{mg} \mathrm{l}^{-1}$, Na: 0.31$0.42 \mathrm{mg} \mathrm{l}^{-1}, \mathrm{NH}_{4}-\mathrm{N}$ : $0.02-0.04 \mathrm{mg} \mathrm{l}^{-1}$ as minimum and maximum annual means at all three soil depths). With increasing soil depth $\mathrm{NO}_{3}-\mathrm{N}$ concentrations decreased, whereas no general trend occurred for cations. $\mathrm{NO}_{3}-$ $\mathrm{N}, \mathrm{Ca}$ and $\mathrm{Mg}$ concentrations were lower in the stream water than in the soil solution, while $\mathrm{Na}, \mathrm{K}$ and $\mathrm{NH}_{4}-\mathrm{N}$ concentrations were higher (Table 2).

\section{Correlation analyses of throughfall fluxes}

A positive correlation between throughfall amount and nutrient fluxes was observed for all nutrients. The closest 
$\square$ Litter percolate $\circ$ Throughfall $\nabla$ Soil solution $15 \mathrm{~cm} \quad$ Throughfall amount
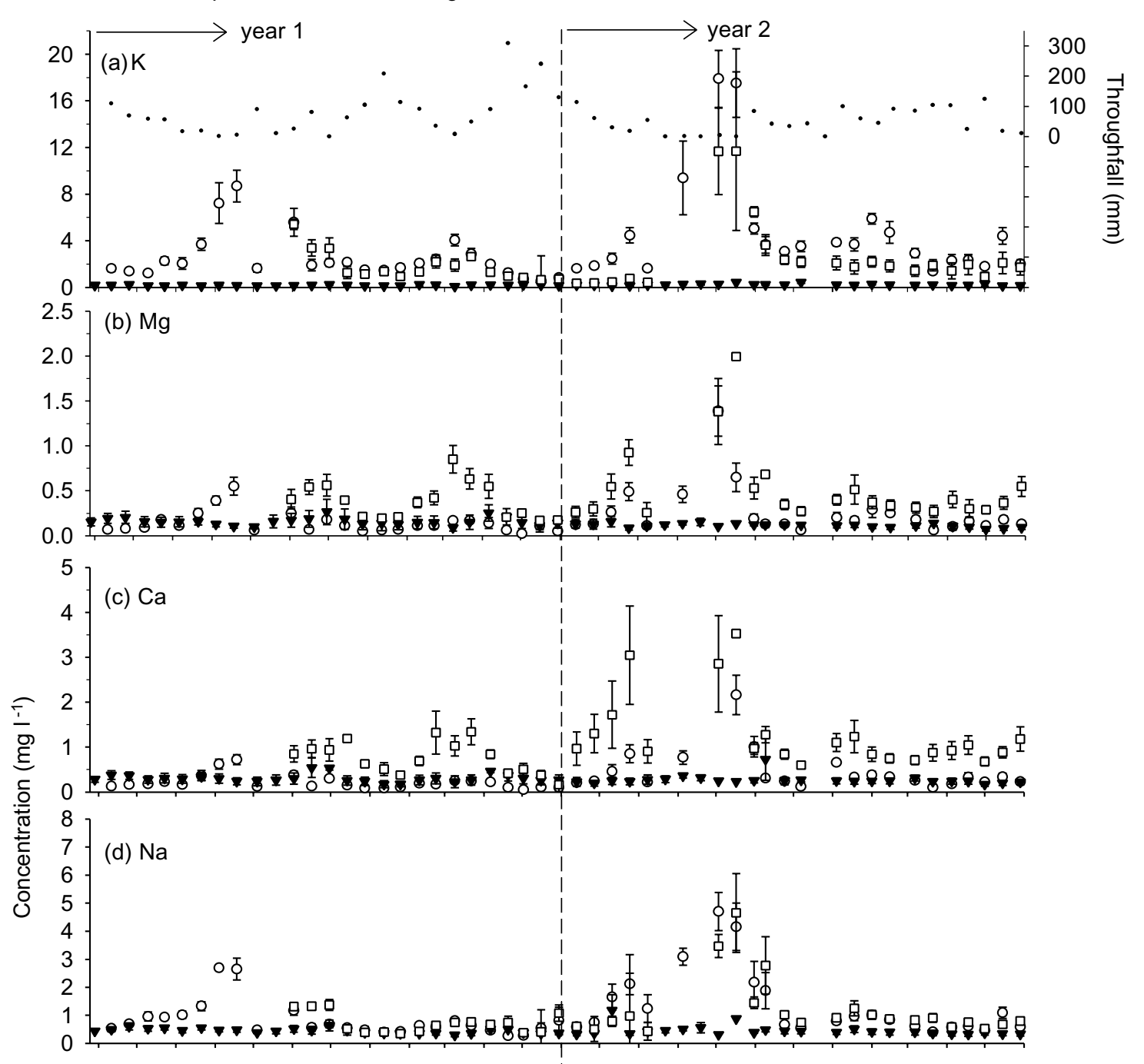

(e) $\mathrm{NH}_{4}-\mathrm{N}$

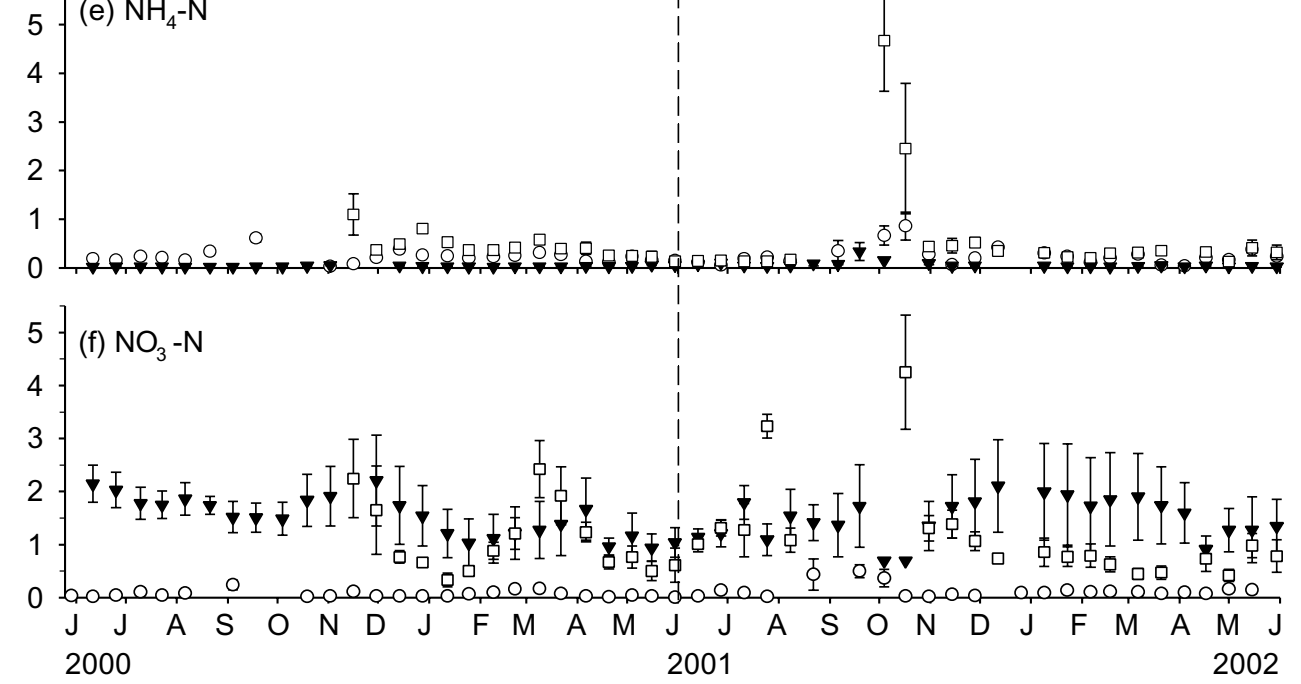

Figure 1. Seasonal variation of concentrations in throughfall, litter percolate and soil solution in a montane rain forest at Mt. Kilimanjaro for 2 consecutive y from June 2000 to May 2002 ( \pm SE, $\mathrm{n}=4$ ). 
Table 4. Results of Pearson Product-Moment correlations between net throughfall fluxes and rainfall amounts at the left side and net throughfall fluxes per mm rain and rainfall concentrations at the right side. Correlation coefficients are given together with the level of significance $(n=17-23)$.

\begin{tabular}{|c|c|c|c|c|}
\hline & \multicolumn{4}{|c|}{ Correlation coefficients } \\
\hline & \multicolumn{2}{|c|}{$\begin{array}{l}\text { Net throughfall fluxes } \\
\text { vs. rainfall amounts }\end{array}$} & \multicolumn{2}{|c|}{$\begin{array}{l}\text { Net throughfall flux per mm rain } \\
\text { vs. rainfall concentrations }\end{array}$} \\
\hline & Year 1 & Year 2 & Year 1 & Year 2 \\
\hline $\mathrm{K}$ & $0.77^{* * * *}$ & $0.62^{* * * *}$ & 0.31 n.s. & -0.17 n.s. \\
\hline $\mathrm{Mg}$ & $0.72^{* * * *}$ & $0.60^{* * *}$ & -0.07 n.s. & $-0.49^{*}$ \\
\hline $\mathrm{Ca}$ & $0.63^{* * * *}$ & 0.36 n.s. & $-0.81^{* * * *}$ & $-0.73^{* * * *}$ \\
\hline $\mathrm{Na}$ & $0.65^{* * * *}$ & 0.37 n.s. & $-0.69^{* * * *}$ & -0.39 n.s. \\
\hline $\mathrm{NH}_{4}-\mathrm{N}$ & 0.37 n.s. & 0.19 n.s. & $-0.62^{* * * *}$ & $-0.76^{* * * *}$ \\
\hline $\mathrm{NO}_{3}-\mathrm{N}$ & 0.11 n.s. & -0.05 n.s. & $-0.95^{* * * *}$ & $-0.97^{* * * *}$ \\
\hline
\end{tabular}

**** $\mathrm{P}<0.001,{ }^{* * *} \mathrm{P}<0.005$, ${ }^{* *} \mathrm{P}<0.01,{ }^{*} \mathrm{P}<0.05$, n.s., not significant.

correlations for both years were obtained for $\mathrm{NH}_{4}-\mathrm{N}$ $(\mathrm{r}=0.84, \mathrm{P}<0.001)$, the weakest for $\mathrm{Ca}(\mathrm{r}=0.45$, $\mathrm{P}<0.001)$. Analysis of net throughfall fluxes gives information on the origin and fate of nutrient ions in the forest canopy. Whilst net fluxes of basic cations were correlated with rainfall amounts in the first year, flux of neither $\mathrm{N}$ form was (Table 4). In the second year, correlations for basic cations were weaker and only significant for $\mathrm{K}$ and $\mathrm{Mg}$. Besides rainfall amounts, the net gain and loss of nutrients in throughfall upon passing the canopy may also be related to the concentrations of individual nutrients in rainfall. On Mt. Kilimanjaro, no significant correlations between concentrations in rainfall and net fluxes per mm rainfall were obtained for $\mathrm{K}$ and $\mathrm{Mg}$, but for $\mathrm{NO}_{3}-\mathrm{N}$, these correlations were very strong $(\mathrm{r}=-0.95, \mathrm{P}<0.001)$. $\mathrm{Ca}, \mathrm{Na}$ and $\mathrm{NH}_{4}-\mathrm{N}$ showed intermediate trends (Table 4 ).

\section{Nutrient input to the forest floor via fine litterfall}

The total amount of fine litterfall was $7.4 \mathrm{tha}^{-1} \mathrm{y}^{-1}$, and it comprised $68 \%$ leaves, $10 \%$ twigs $<2$ mm diameter, $4 \%$ mosses and lichens, and a huge part of $18 \%$ consisting of unidentified material such as flowers, other reproductive parts and small leaf parts. Total annual nutrient fluxes of $\mathrm{N}, \mathrm{P}, \mathrm{K}, \mathrm{Mg}, \mathrm{Ca}, \mathrm{Na}$ and $\mathrm{S}$ via fine litter were $119,6,25$, $16,69,4$ and $12 \mathrm{~kg} \mathrm{ha}^{-1} \mathrm{y}^{-1}$ respectively. The seasonal pattern of nutrient fluxes followed the monthly amounts of fine litterfall, with the highest inputs between the end of the dry season and the beginning of the minor rains in December and January (Figure 2). While annual nutrient fluxes via fine litter exceeded the fluxes in throughfall for $\mathrm{Ca}$ and $\mathrm{Mg}$, the opposite held true for $\mathrm{K}$ and $\mathrm{Na}$ (Tables 3 and 5).

Nutrient concentrations in fine litter samples did not correlate with the corresponding amount of litterfall. Mean concentrations of base cations in fine litter were higher than in the litter layer, while there were no differences in the case of $\mathrm{N}$, and $\mathrm{P}$ concentrations were even higher in the litter layer (Table 5).

\section{DISCUSSION}

\section{Rainwater chemistry on Mt. Kilimanjaro}

Possible sources for solutes in rainfall on Mt. Kilimanjaro are volcanic emissions, oceanic sprays or terrestrial dust. Terrestrial dust sources include ashes from burning of organic material (forest fires, burning of harvest residues, house fires) and eroded soil particles. Most natural forest and savanna fires occur at the end of the dry seasons, which is also the time when vegetation residues are burnt on the fields below the forest belt, leaving them unprotected against wind erosion. Different from many other tropical montane rain forests of the more humid tropics, Mt. Kilimanjaro is surrounded by a semi-arid environment where salt accumulation frequently occurs at ephemeral ponds, the edges of salt lakes and on irrigated fields (Wakatsuki \& Mizota 1992). As shown by Prospero (1999), the African savanna plains have a high winderosion potential, and dust is often transported over great distances. Thus, additions of salt-rich particles to dry deposition seem likely on Mt. Kilimanjaro. Mizota et al. (1988) detected an addition of soil particles from the savanna plains to a soil profile in Machame (a village below the study area) at $1600 \mathrm{~m}$. Their results were supported by the frequent occurrence of dust storms and vortices of different magnitudes in the savanna, especially during the dry season.

Thus, it might be assumed that comparatively high amounts of salts may enter the studied forest at Mt. Kilimanjaro via rainfall. But a comparison with a

Table 5. Volume weighted mean nutrient concentrations in the Oi litter layer and in fine litterfall collected in a montane rain forest at Mt. Kilimanjaro and annual nutrient fluxes via fine litterfall $( \pm$ SE, $n=3)$.

\begin{tabular}{|c|c|c|c|c|c|c|c|}
\hline & $\mathrm{K}$ & $\mathrm{Mg}$ & $\mathrm{Ca}$ & $\mathrm{Na}$ & $\mathrm{N}$ & $\mathrm{P}$ & $S$ \\
\hline $\begin{array}{l}\text { Oi-layer } \\
\quad\left(\mathrm{g} \mathrm{kg}^{-1}\right)\end{array}$ & $1.54 \pm 0.10$ & $1.92 \pm 0.05$ & $7.93 \pm 1.37$ & $0.36 \pm 0.06$ & $16 \pm 0.2$ & $1.09 \pm 0.15$ & $1.82 \pm 0.03$ \\
\hline $\begin{array}{l}\text { Fine litter } \\
\quad\left(\mathrm{g} \mathrm{kg}^{-1}\right) \\
\quad\left(\mathrm{kg} \mathrm{ha}^{-1} \mathrm{y}^{-1}\right)\end{array}$ & $\begin{array}{l}3.45 \pm 0.23 \\
25.3 \pm 3.6\end{array}$ & $\begin{array}{l}2.17 \pm 0.11 \\
15.8 \pm 1.4\end{array}$ & $\begin{array}{l}9.42 \pm 0.95 \\
68.5 \pm 9.1\end{array}$ & $\begin{array}{c}0.49 \pm 0.05 \\
3.6 \pm 0.7\end{array}$ & $\begin{array}{r}16 \pm 1.1 \\
119 \pm 13\end{array}$ & $\begin{array}{c}0.82 \pm 0.08 \\
5.9 \pm 0.5\end{array}$ & $\begin{array}{l}1.69 \pm 0.09 \\
12.4 \pm 1.5\end{array}$ \\
\hline
\end{tabular}




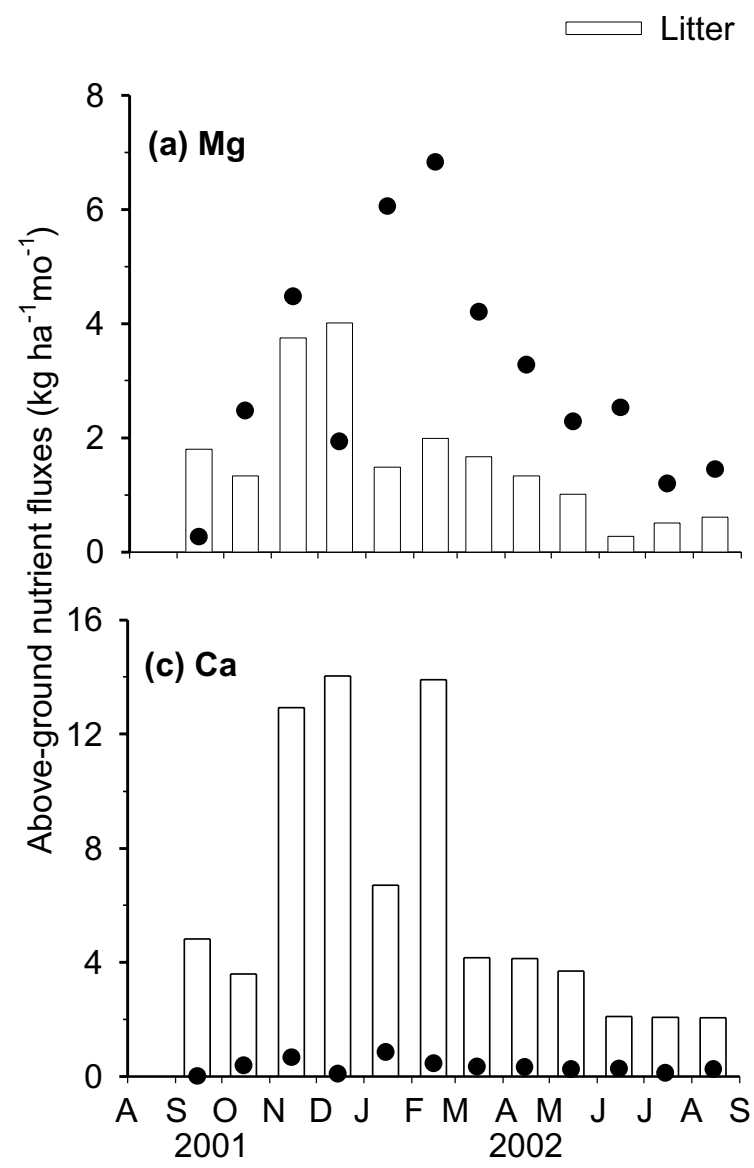

- Throughfall
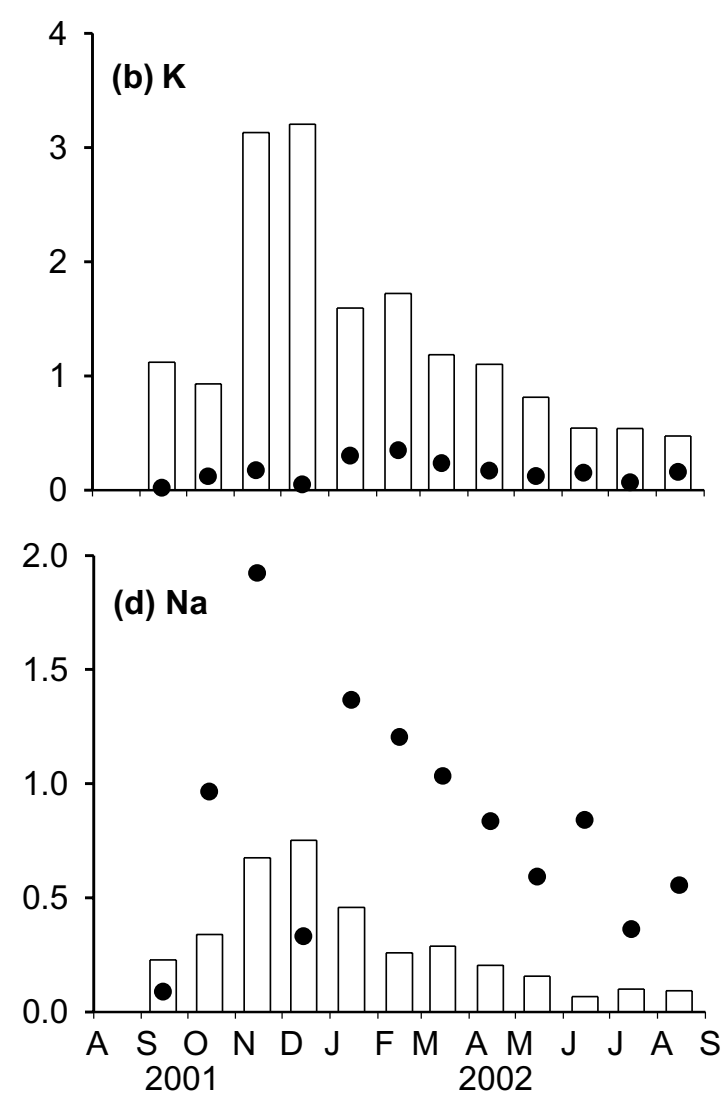

Figure 2. Comparison of the seasonal distribution of monthly fluxes in fine litterfall and throughfall in a montane rain forest at Mt. Kilimanjaro from September 2001 to August 2002.

number of other montane rain forests summarized in Table 6 reveals in contrast that fluxes for $\mathrm{Ca}$ and $\mathrm{Mg}$ were quite low at Mt. Kilimanjaro. While Ca exhibited overall lowest values $\left(2 \mathrm{~kg} \mathrm{ha}^{-1} \mathrm{y}^{-1}\right.$ compared with 4$47 \mathrm{~kg} \mathrm{ha}^{-1} \mathrm{y}^{-1}$ at other sites), only an upper montane rain forest (UMRF) in Costa Rica revealed lower Mg fluxes than the study sites on Mt. Kilimanjaro, and also Na fluxes were at the lower end of fluxes encountered in tropical montane rain forests. $\mathrm{N}$ and $\mathrm{K}$ fluxes on the other hand were within the range typically observed in these forests.

One explanation for the low input of salts via rainfall is a strong decrease in dry deposition with increasing elevation on Mt. Kilimanjaro. At about 1500 m, the vertical difference between the savanna plains (around $800 \mathrm{~m}$ ) and the study sites $(2250 \mathrm{~m})$ is large. As the area below the forest belt at the southern slope of Mt. Kilimanjaro is managed as agroforest, the soil surface is permanently covered and hence protected against erosion. Similarly, ion additions from marine sources seem to be low, which is probably due to the distance to the coast (around $200 \mathrm{~km}$ ). For the detection of possible impacts of sea water on the nutrient composition in rainfall, an 'excess amounts' approach suggested by Eriksson (1960) has often been used in the literature (Bruijnzeel 1989, Waterloo et al. 1997, Wilcke et al. 2001). Applied to the present study, this method reveals that $\mathrm{Na}$ and $\mathrm{Mg}$ concentrations in rainfall did not match the $\mathrm{Cl}$ content during both the wet and dry seasons (although differences were smaller during the wet season). Bruijnzeel (1989) also observed a surplus of $\mathrm{Cl}$ over expected values of $\mathrm{Na}$ in rainwater of Java and ascribed this to additional non-maritime inputs by volcanic activity. This might also have been the case on Mt. Kilimanjaro, which is part of the volcanically active East African rift valley. For $\mathrm{K}$ and $\mathrm{Ca}$ on the other hand, concentrations by far exceeded supposed maritime concentrations, thus indicating a high contribution of dust to total fluxes (at least $80 \%$ for Ca and $95 \%$ for K). As in the present study a coarser water filter was used than in many other studies $(<2 \mu \mathrm{m}$ instead of $0.45 \mu \mathrm{m})$, solute concentrations are rather over- than underestimated so that it can be concluded that cation inputs in the forest belt on the south-western slopes of the mountain are unexpectedly low. 
Table 6. Nutrient fluxes in rainfall and throughfall of different tropical montane rain-forest ecosystems. For details on forest types, elevation, annual rainfall amounts and soil types, see footnotes.

\begin{tabular}{|c|c|c|c|c|c|c|c|c|c|c|c|c|}
\hline & \multicolumn{6}{|c|}{ Rainfall flux $\left(\mathrm{kg} \mathrm{ha}^{-1} \mathrm{y}^{-1}\right)$} & \multicolumn{6}{|c|}{ Throughfall flux $\left(\mathrm{kg} \mathrm{ha}^{-1} \mathrm{y}^{-1}\right)$} \\
\hline & K & $\mathrm{Mg}$ & $\mathrm{Ca}$ & $\mathrm{Na}$ & $\mathrm{NH}_{4}-\mathrm{N}$ & $\mathrm{NO}_{3}-\mathrm{N}$ & K & $\mathrm{Mg}$ & $\mathrm{Ca}$ & $\mathrm{Na}$ & $\mathrm{NH}_{4}-\mathrm{N}$ & $\mathrm{NO}_{3}-\mathrm{N}$ \\
\hline Ecuador $^{1}$ & 3.7 & 1.2 & 3.9 & 19 & 2.6 & 3.0 & $76-166$ & $7-21$ & $15-28$ & $10-22$ & $3-7$ & $5.9-8.6$ \\
\hline Venezuela $^{2}$ & 2.6 & 5.2 & 5.6 & 3.3 & & & 70 & 3.3 & 6.9 & 4.4 & & \\
\hline Malaysia $^{3}$ & 4 & 1.2 & 4 & & 2.5 & 5 & 23 & 7 & 12 & & 9 & 10 \\
\hline Puerto Rico ${ }^{4}$ & 4.7 & 8.5 & 13 & 63 & 0.7 & 1.2 & 52 & 13 & 23 & 81 & 3.3 & 0.2 \\
\hline Costa Rica 5 & 5.8 & 0.7 & 4.0 & 3.0 & 1.4 & 1.7 & 62 & 5.6 & 15 & 3.2 & 3.4 & 0.6 \\
\hline Jamaica $1^{6}$ & 8.3 & 2.0 & 9.0 & 21 & 3.9 & 1.7 & 44 & 5.9 & 13 & 30 & 4.8 & 0.7 \\
\hline Jamaica $2^{7}$ & 8.3 & 2.0 & 9.0 & 21 & 3.9 & 1.7 & 33 & 6.4 & 12 & 23 & 3.9 & 0.7 \\
\hline Tanzania $^{8}$ & $6.9-8.0$ & $0.8-0.9$ & $2.1-2.4$ & $5.7-6.7$ & $2.5-3.6$ & $2.2-3.0$ & $32-37$ & 2.0 & $3-4$ & 11 & $2-4$ & $0.7-1.0$ \\
\hline \multicolumn{13}{|c|}{ Published range in Hafkenscheid (2000) } \\
\hline $\begin{array}{l}\text { LMRF } \mathrm{n}=5 \\
\text { Intermediate }\end{array}$ & $2.6-14$ & $1.3-5.2$ & $3.6-28$ & $3.3-64$ & $1.7-18$ & 1.7 & $63-95$ & $3.3-12$ & $6.9-35$ & $4.4-131$ & $1.3-22$ & 0.6 \\
\hline $\mathrm{UMRF} \mathrm{n}=3$ & $6.9-8.3$ & $2.0-5.0$ & $5.5-9.0$ & $16-21$ & $3.9-11$ & 1.7 & $33-56$ & $5.9-9.8$ & $11-19$ & $14-30$ & $4.8-12$ & 0.7 \\
\hline Stunted & & & & & & & & & & & & \\
\hline UMRF $\mathrm{n}=3$ & $7.1-27$ & $2.0-30$ & $5.5-47$ & $20-247$ & $3.9-6.9$ & $1.7-5.3$ & $24-77$ & $6.4-91$ & $12-109$ & $23-692$ & $3.9-5.1$ & $0.7-15$ \\
\hline
\end{tabular}

${ }^{1}$ Wilcke et al. (2002): Ecuador, 1900-2010 m, LMRF, 2190 mm, Dystrudepts, Eutrudepts.

${ }^{2}$ Steinhardt (1979): Venezuela, $2300 \mathrm{~m}$, LMRF, $1500 \mathrm{~mm}$, Humitropepts.

${ }^{3}$ Bruijnzeel et al. (1993): Malaysia, $870 \mathrm{~m}$, LMRF, $2130 \mathrm{~mm}$, Dystropepts, approximation from $6 \mathrm{wk}$.

${ }^{4}$ McDowell (1998): Puerto Rico, 390 m, LMRF, 3500 mm, Ultisols.

${ }^{5}$ Hölscher et al. (2003): Costa Rica, 2900 m, UMRF, 2830 mm, Humic Andosols.

${ }^{6}$ Hafkenscheid (2000): Jamaica, 1800 m, intermediate UMRF, 2310 mm, Dystric Cambisols.

${ }^{7}$ Hafkenscheid (2000): Jamaica, 1800 m, stunted UMRF, 2180 mm, Folic Histosols.

${ }^{8}$ This study: Tanzania, 2300 m, TMF, 2220 mm, Endoaquands, Fulvaquands.

LMRF: lower montane rain forest, UMRF: upper montane rain forest, TMF: tropical montane rain forest.

\section{Throughfall chemistry}

The composition of rainfall is usually altered during the passage through the forest canopy by processes like washoff of wet- and dry-deposited material, passive leaching from plant tissues, ion exchange or adsorption. Further, leaching from or ion exchange in canopy humus can add to throughfall fluxes (Nadkarni et al. 2002).

A high accumulation of dust particles on plant tissues was expected during the dry season on Mt. Kilimanjaro, which should lead to increased throughfall concentrations and fluxes following wash-off and dilution. But similar to rainfall fluxes, throughfall fluxes of base cations were unexpectedly low on Mt. Kilimanjaro as compared to other tropical montane rain-forest sites (Table 6). Throughfall fluxes for $\mathrm{Mg}$ and $\mathrm{Ca}$ were the lowest values observed and $\mathrm{K}$ fluxes were also at the lower end. A comparison of the enrichment factors (throughfall fluxes divided by rainfall fluxes) reveals that with a value of 5, the enrichment factor for $\mathrm{K}$ was also low on Mt. Kilimanjaro compared with lower montane rain forest (LMRF) elsewhere (5-45, values from Hafkenscheid (2000) and calculated from Table 6) and was closer to values of UMRF (3-11). At one montane rain-forest site in Venezuela (Steinhardt 1979), a net absorption of $\mathrm{Mg}$ was observed, while an enrichment between 1.5 and 17.5 was measured for other LMRF. With 2.4, the enrichment factor for $\mathrm{Mg}$ was again at the lower end at Mt. Kilimanjaro. Enrichment factors were also low for
Ca (1.6) but within the range at other sites (1.2-7.2). Highest overall values were always observed at a LMRF in Ecuador (Wilcke et al. 2001), which had a distinctly lower tree height than the forest on Mt. Kilimanjaro and grew on acidic soils developed on Palaeozoic schists and sandstones. Otherwise, rainfall regime and altitude were comparable to Mt. Kilimanjaro. Unfortunately, Wilcke et al. (2001) present no explanation for their high enrichment factors, which might partly be related to fires and volcanic activity in the region. On Mt. Kilimanjaro, no fires occurred in the vicinity of the plots during the study period. That might be different during dry El Niño years, when forest fires are more frequent (Hemp \& Beck 2001). Overall it seems that similar to low rainfall fluxes, low throughfall fluxes of base cations result from the great altitudinal and vertical distance between various dust sources and the studied forest sites during most years, leading to low nutrient additions via dry deposition.

The contribution of internal and external sources to ion enrichment in rainfall during the passage through the forest canopy can only indirectly be assessed from the available data. Ion additions to throughfall water by dry deposition are not expected to depend on rainfall amounts as long as the rainfall amount is high enough to remove all the deposited material. Thus, the dependency of net throughfall fluxes of base cations on rainfall amounts observed in our study indicates that passive leaching processes from leaves or ion exchange do contribute to throughfall fluxes on Mt. Kilimanjaro. The 
relation between net throughfall fluxes of $\mathrm{Ca}$ and $\mathrm{Ca}$ concentrations in rainfall further hints that ion exchange is involved in $\mathrm{Ca}$ enrichment on the passage of rain through the forest canopies. In a lowland rain forest in the Amazon Basin with low nutrient fluxes in rainfall, Filoso et al. (1999) observed high contributions of canopy leaching to net throughfall fluxes of $\mathrm{Mg}$ and $\mathrm{Ca}$.

Nitrogen fluxes in throughfall were low but overall within the range of other tropical montane forest sites (Table 6). In the majority of forests presented in Table 6, $\mathrm{NO}_{3}-\mathrm{N}$ was not leached, but absorbed in the forest canopies. The absorption of $\mathrm{NO}_{3}-\mathrm{N}$ by montane forest canopies has usually been ascribed to the epiphytic coverage (Clark et al. 1998, Liu et al. 2002). Unlike the base cations, net throughfall fluxes of $\mathrm{NO}_{3}-\mathrm{N}$ and $\mathrm{NH}_{4}-$ $\mathrm{N}$ did not show a dependency on water fluxes. Negative correlations with rainfall concentrations indicate that ion uptake or release depends on $\mathrm{N}$ concentrations. High $\mathrm{N}$ concentrations in rainfall result in a net absorption of $\mathrm{N}$ in the canopy, while lower concentrations lead to net leaching. Veneklaas (1990) made similar observations in an upper montane cloud forest in Colombia.

\section{Water chemistry in litter percolate and soil solution}

Very few studies on nutrient cycling in tropical montane ecosystems include the chemistry of below-ground seepage water. A limitation of the present study and some others for the comparability among different rainforest sites is that only concentrations, not fluxes, are available due to a lack of climatic and runoff data. The composition of litter percolate was determined with two different approaches in the literature. In Jamaica (Hafkenscheid 2000) and Malaysia (Bruijnzeel et al. 1993) litter percolate was collected directly below the leaf-litter-layer (Oi-horizon), thus providing information on the leaching of nutrients from freshly shed litter. In other studies, the focus was more on the input of nutrients from the litter layer into the mineral soil. Thus, litter percolate was collected between the Oa-horizon and the mineral soil in studies in Ecuador (Wilcke et al. 2001), Venezuela (Steinhardt 1979) and the present study. Since the composition of seepage water is altered on the passage through different parts of the litter layer by further leaching from organic material or root uptake, the concentrations in litter percolate between the different sites summarized in Table 7 are not fully comparable.

Keeping that problem in mind, the concentrations of nutrients in the litter percolate of the forest on Mt. Kilimanjaro, especially those of basic cations, were low compared with other montane rain-forest sites. Since throughfall amounts are often correlated to the amounts of litter percolate (Wilcke et al. 2001), and these were within the range of other forest sites at Mt. Kilimanjaro,
Table 7. Nutrient concentrations $\left(\mathrm{mg} \mathrm{l}^{-1}\right)$ in litter percolate of different tropical montane rain-forest ecosystems. For details on forest types, elevation, annual rainfall amounts and soil types, see footnotes.

\begin{tabular}{lcccccc}
\hline & $\mathrm{K}$ & $\mathrm{Mg}$ & $\mathrm{Ca}$ & $\mathrm{Na}$ & $\mathrm{NH}_{4}-\mathrm{N}$ & $\mathrm{NO}_{3}-\mathrm{N}$ \\
\hline Ecuador $^{1}$ & $0.4-28$ & $1.4-5.0$ & $0.3-8.0$ & $1.4-1.5$ & $0.3-0.7$ & $0.6-5.7$ \\
Venezuela $^{2}$ & 38 & 2.1 & 5.1 & 0.4 & & $4.6^{+}$ \\
Malaysia $^{3}$ & 5.1 & 2.5 & 4.6 & 5.2 & 1.0 & 8.4 \\
Malaysia $^{4}$ & 3.6 & 2.7 & 5.7 & 3.6 & 1.0 & 6.5 \\
Jamaica $^{5}$ & 4.1 & 1.1 & 2.5 & 2.0 & 0.2 & 0.2 \\
Jamaica $^{6}$ & 2.9 & 0.9 & 1.7 & 1.6 & 0.1 & 0.0 \\
Tanzania $^{7}$ & 1.4 & 0.3 & 0.8 & 0.8 & 0.3 & 0.9 \\
\hline
\end{tabular}

${ }^{1}$ Wilcke et al. (2002): Ecuador, 1900-2010 m, LMRF, 2190 mm, Dystrudepts, Eutrudepts.

${ }^{2}$ Steinhardt (1979): Venezuela, 2300 m, LMRF, 1500 mm, Humitropepts.

${ }^{3}$ Bruijnzeel et al. (1993): Malaysia, $680 \mathrm{~m}$, LMRF, $2130 \mathrm{~mm}$, Dystropepts, approximation from $6 \mathrm{wk}$.

${ }^{4}$ Bruijnzeel et al. (1993): Malaysia, $870 \mathrm{~m}$, LMRF, $2130 \mathrm{~mm}$, Dystropepts, approximation from $6 \mathrm{wk}$.

${ }^{5}$ Hafkenscheid (2000): Jamaica, $1800 \mathrm{~m}$, intermediate UMRF, 2310 mm, Dystric Cambisols.

${ }^{6}$ Hafkenscheid (2000): Jamaica, 1800 m, stunted UMRF, $2180 \mathrm{~mm}$, Folic Histosols.

7 This study: Tanzania, 2300 m, TMF, 2220 mm, Endoaquands, Fulvaquands.

LMRF: lower montane rain forest, UMRF: upper montane rain forest, TMF: tropical montane rain forest.

it might be assumed that fluxes of $\mathrm{K}, \mathrm{Ca}$ and $\mathrm{Mg}$ in litter percolate were also comparatively low. Among possible reasons are low inputs via throughfall (see section above), a low release from the organic layer or a high nutrient uptake.

A comparison of the nutrient composition of the litter layer reveals that concentrations of $\mathrm{K}, \mathrm{Mg}$ and $\mathrm{Ca}$ were lower in the Oi layer at Mt. Kilimanjaro (1.5, 1.9 and $7.9 \mathrm{~g} \mathrm{~kg}^{-1}$ respectively) compared with the forest in Venezuela (2.1, 2.5 and $10 \mathrm{~g} \mathrm{~kg}^{-1}$, Steinhardt 1979) and Ecuador (2.6, 3.4 and $10 \mathrm{~g} \mathrm{~kg}^{-1}$, Wilcke et al. 2002). N concentrations exhibited intermediate values in the litter layer $\left(16 \mathrm{~g} \mathrm{~kg}^{-1}\right.$ in the present study versus $11 \mathrm{~g} \mathrm{~kg}^{-1}$ in Venezuela and $17 \mathrm{~g} \mathrm{~kg}^{-1}$ in Ecuador).

On Mt. Kilimanjaro, concentrations of $\mathrm{Mg}, \mathrm{Ca}$ and $\mathrm{NO}_{3}-\mathrm{N}$ in litter percolate were higher overall than in throughfall, indicating that additional ion release in the litter layer exceeded the ion uptake by roots for these ions. On the other hand annual mean $\mathrm{K}$ concentrations in litter percolate were lower than in throughfall water. This was unexpected since $\mathrm{K}$ is easily leached from freshly fallen litter (Lundgren 1978, Tukey 1970) and should thus be further enriched in the litter percolate. Potential sinks for $\mathrm{K}$ are adsorption and exchange processes with soil organic material or ion uptake by roots and mycorrhizas. As organic matter preferentially binds polyvalent cations, the ion exchange sites were dominated by $\mathrm{Al}, \mathrm{Mg}$ and Ca (Al: 10.45, Ca: 6.08, Mg: 3.15, K: 0.89 and Na $\left.0.33 \mathrm{cmol}_{\mathrm{c}} \mathrm{kg}^{-1}\right)$. Therefore, cation exchange is not likely to be a strong sink for $\mathrm{K}$. This indicates that a large 
quantity of $\mathrm{K}$ is readily taken up by roots or mycorrhizas in the uppermost litter layers.

A pronounced decrease in ion concentrations from the litter layer to the mineral soil was similarly observed at other sites with nutrient-depleted, weathered soils in the humid tropics (Bruijnzeel et al. 1993, Hafkenscheid 2000, Lilienfein et al. 2000). Still, solute concentrations obtained by zero-tension litter percolate collectors and suction cups are not totally comparable. Firstly, by using negative pressure, additional solution is extracted that would not be obtained with free draining lysimeters, which can lead to different concentrations depending on the suction applied (Marques et al. 1996). Furthermore, collectors for litter percolate accumulated seepage water for the whole period between two sampling days, while suction cups only collected water during one day. Thus, individual peaks of nutrient concentrations during the week might not be registered with the suction cups.

Similar to litter percolate, also concentrations of K, $\mathrm{Mg}, \mathrm{Ca}$ and $\mathrm{Na}$ in the soil solution in $0.2 \mathrm{~m}$ soil depth were higher at a tall LMRF in Venezuela (1.4, 0.6, 0.8 and $0.6 \mathrm{mgl}^{-1}$ respectively, Steinhardt 1979) than on Mt. Kilimanjaro $\left(0.2,0.1-0.2,0.3,0.4 \mathrm{mg} \mathrm{l}^{-1}\right.$ respectively in $0.15 \mathrm{~m}$ soil depth). Similarly, with $0.9-1.0 \mathrm{~g} \mathrm{~kg}^{-1}$ $\mathrm{K}, 0.5-0.8 \mathrm{~g} \mathrm{~kg}^{-1} \mathrm{Mg}, 0.5-0.6 \mathrm{~g} \mathrm{~kg}^{-1} \mathrm{Ca}$ and $1.7 \mathrm{~g} \mathrm{~kg}^{-1}$ $\mathrm{Na}$, concentrations were also higher at two UMRF of contrasting stature in Jamaica. In the present study, soils are already in an advanced stage of weathering with a low cation exchange capacity and base saturation. This indicates that the stocks of nutrients easily available to plants in the mineral soil as well as its retention capacity for nutrients leached from the organic layer are rather low. The same was true for the other two montane rainforest sites. Thus, plant uptake seems to be more important for the reduction of ion concentrations in the soil solution than the sorption of ions to particles in the mineral soil. Low concentrations of base cations in the soil solution indicate that the overall losses of these ions via leaching will be low at Mt. Kilimanjaro, especially for K. The only exception for the general trend of reduced concentrations in the soil solution as compared to the litter percolate was the concentration of $\mathrm{NO}_{3}-\mathrm{N}$, which increased from litter percolate to the soil solution. This may be related to $\mathrm{N}$ mineralization and nitrification of $\mathrm{NH}_{4}-\mathrm{N}$ below the litter layer. Since the concentration of base cations in the soil solution was low, $\mathrm{Al}$ and $\mathrm{H}$ were most likely the cations accompanying $\mathrm{NO}_{3}-\mathrm{N}$ for charge compensation.

\section{Nutrients in fine litterfall}

Nutrient concentrations in fine litterfall are widely believed to be a suitable indicator for the nutrient status of a forest and the tightness of the nutrient cycle (Vitousek 1984). The concentrations of $\mathrm{K}, \mathrm{Mg}$,
$\mathrm{Ca}$ and $\mathrm{Na}$ in litterfall on Mt. Kilimanjaro were within the range observed at other tropical montane rainforests as summarized in Hafkenscheid (2000). Litter $\mathrm{P}$ concentrations $\left(0.82 \mathrm{~g} \mathrm{~kg}^{-1}\right)$ were at the higher end and $\mathrm{N}$ concentrations $\left(16.3 \mathrm{~g} \mathrm{~kg}^{-1}\right)$ were higher than the range of $0.17-0.95 \mathrm{~g} \mathrm{~kg}^{-1} \mathrm{P}$ and $6-15 \mathrm{~g} \mathrm{~kg}^{-1} \mathrm{~N}$ presented in Hafkenscheid (2000) for a number of montane rain forests. On the other hand, litter N, P and S concentrations of a montane rain forest in Ecuador (Wilcke et al. 2002) exceeded the values measured on Mt. Kilimanjaro with values between $19-22 \mathrm{~g} \mathrm{~kg}^{-1} \mathrm{~N}, 0.9-1.6 \mathrm{~g} \mathrm{~kg}^{-1} \mathrm{P}$ and $2.3-2.4 \mathrm{~g} \mathrm{~kg}^{-1} \mathrm{~S}$. In a montane rain forest in the West Usambara Mts., Lundgren (1978) measured similar litter concentrations than the ones obtained on Mt. Kilimanjaro (17.6 g kg-1 N, $1.0 \mathrm{~g} \mathrm{~kg}^{-1} \mathrm{P}, 4.3 \mathrm{~g} \mathrm{~kg}^{-1} \mathrm{~K}, 12,7 \mathrm{~g} \mathrm{~kg}^{-1} \mathrm{Ca}$ and $3.0 \mathrm{~g} \mathrm{~kg}^{-1} \mathrm{Mg}$ in Mazumbai Forest Reserve at 1400$1900 \mathrm{~m}$, LMRF with canopy heights of 35-40 m situated about $300 \mathrm{~km}$ south-east of Mt. Kilimanjaro).

Tanner et al. (1998) found a positive correlation between canopy height and $\mathrm{N}$ concentrations in leaves. A similar, but weaker correlation was obtained for litter P concentrations. The combination of tall canopy height and high $\mathrm{N}$ and $\mathrm{P}$ concentrations of the litter at Mt. Kilimanjaro fit well in the correlations presented by Tanner et al. (1998).

Montane rain forests exhibit an overall tendency for low $\mathrm{N}$ concentrations and fluxes in litterfall as compared to lowland rain forests (Bruijnzeel \& Proctor 1995, Tanner et al. 1998). Vitousek (1984) suggested the litter amount/nutrient flux ratio as a measure of the nutrient use efficiency of a forest. According to his reference forests, montane rain forests usually have lower $\mathrm{N}$ and $\mathrm{P}$ cycling rates and a higher within-stand efficiency. With canopy heights of over $40 \mathrm{~m}$ for some Ocotea trees, the stature of the forest on Mt. Kilimanjaro more resembles statures of lower montane rain forests (Grubb 1977). Accordingly, also the ratio between litter dry mass/nutrient flux of the forest on Mt. Kilimanjaro ( 62 for N and 1254 for P) more strongly resembles lower montane rain forests with a higher $\mathrm{N}$ and $\mathrm{P}$ circulation. The overall results from Mt. Kilimanjaro indicate that $\mathrm{N}$ and $\mathrm{P}$ are not major growthlimiting factors for the montane rain forest.

\section{CONCLUSIONS}

Contrary to expectations, above-ground nutrient fluxes of base cations in rainfall and throughfall were very low on Mt. Kilimanjaro compared to other tropical montane rain forests. This was especially true for $\mathrm{Mg}$ and $\mathrm{Ca}$. The low fluxes are most likely related to the large altitudinal distance between forest and surrounding savanna plains, which otherwise form an extensive source for terrestrial salt-rich dust. Furthermore, the large distance to the sea limits inputs from this potential source. Thus, the 
amount of base cations reaching the soil via throughfall was comparatively low. The pronounced decline in cation concentrations from litter percolate to the soil solution indicates that these ions are retained within the ecosystem. $\mathrm{K}$ in particular seems to be held in a relatively closed cycle between forest canopy and soil litter layer.

Nutrient concentrations and annual fluxes of fine litterfall on Mt. Kilimanjaro were in the range observed in other tropical montane forests. However, high litter $\mathrm{N}$ and $\mathrm{P}$ concentrations and fluxes indicate high circulation rates, so that $\mathrm{N}$ or $\mathrm{P}$ limitations are not expected to be an important factor in this ecosystem.

In order to get a better insight into the nutrient availability and usage by plants, biogeochemical studies in montane rain forest should also include analyses of below-ground water and soil chemistry. For studying internal nutrient transfers within ecosystems as well as for comparisons between different sites, nutrient fluxes are more meaningful than concentrations, since they are independent of the amount of the transport medium: water. Therefore, it is important that future studies on seepage water will also include estimates of water fluxes.

\section{ACKNOWLEDGEMENTS}

This study was supported by a grant from the German Science Foundation (DFG, Ze 154/1-4). Furthermore we are greatly indebted to the following organizations: Department of Mines and Minerals Tanzania, Forestry and Beekeeping Division Tanzania (FBD), Kilimanjaro National Park (KINAPA), Tanzania National Park (TANAPA) and the Tanzania Commission for Science and Technology (COSTECH).

\section{LITERATURE CITED}

AXMACHER, J. C. 2003. Diversität von Geometriden (Lepidoptera) und Gefäßpflanzen entlang von Habitatgradienten am Südwest-Kilimanjaro, $\mathrm{PhD}$ thesis, Institute of Biogeography, University of Bayreuth. $301 \mathrm{pp}$.

BJØRNDALEN, J. E. 1992. Tanzania's vanishing rain forests assessment of nature conservation values, biodiversity and importance for water catchment. Agriculture, Ecosystems and Environment 40:313-334.

BRUIJNZEEL, L. A. 1989. Nutrient content of bulk precipitation in south-central Java, Indonesia. Journal of Tropical Ecology 5:187-202.

BRUIJNZEEL, L. A. 2001. Hydrology of tropical montane cloud forests: a Reassessement. Land Use and Water Resources Research 1:1-18.

BRUIJNZEEL, L. A. 2004. Hydrological functions of tropical forests: not seeing the soil for the trees? Agriculture Ecosystems and Environment 104:185-228.

BRUIJNZEEL, L. A. \& PROCTOR, J. 1995. Hydrology and biogeochemistry of tropical montane cloud forests: what do we really know?
Pp. 38-78 in Hamilton, L. S., Juvik, J. O. \& Scatena, F. N. (ed.). Tropical montane cloud forests. Ecological Studies 110. Springer, Berlin.

BRUIJNZEEL, L. A., WATERLOO, M. J., PROCTOR, J., KUITERS, A. T. \& KOTTERINK, B. 1993. Hydrological observations in montane rain forests on Gunung Silam, Sabah, Malaysia, with special reference to the "Massenerhebung" effect. Journal of Ecology 81:145-167.

BUBB, P., MAY, I., MILES, L. \& SAYER, J. 2004. Cloud forest agenda. UNEP-WCMC, Cambridge. 36 pp.

BURT, R. 1996. Soil Survey Laboratory methods manual. Soil Survey Investigations Report SSIR No. 42 Version 3, USDA, NRCS, NSSC. 716 pp.

ClARK, K. L., NADKARNI, N. M., SCHAEFER, D. \& GHOLZ, H. L. 1998. Cloud water and precipitation chemistry in a tropical montane forest, Monteverde, Cost Rica. Atmospheric Environment 32:15951603.

DOWNIE, C. \& WILKINSON, P. 1972. The geology of Kilimanjaro. University of Sheffield, Sheffield. $253 \mathrm{pp}$.

ERIKSSON, E. 1960. The yearly circulation of chloride and sulfur in nature - meteorological, geochemical and pedological implications 2. Tellus 12:63-109.

FILOSO, S., WILLIAMS, M. R. \& MELACK, J. M. 1999. Composition and deposition of throughfall in a flooded forest archipelago. Biogeochemistry 45:169-195.

GEE, G. W. \& BAUDER, J. W. 1986. Particle-size analysis. Pp. 383-411 in Klute, A. K. (ed.). Methods of soil analysis. Part 1: Physical and mineralogical methods. SSSA, Madison.

GRUBB, P. J. 1977. Control of forest growth and distribution on wet tropical mountains: with special reference to mineral nutrition. Annual Review of Ecology and Systematics 8:83-107.

HAFKENSCHEID, R. 2000. Hydrology and biogeochemistry of tropical montane rain forests of contrasting stature in the Blue Mountains, Jamaica, Ph.D. thesis, Free University of Amsterdam. 302 pp.

HEINRICHS, H., BRUMSACK, H.-J., LOFTFIELD, N. \& KÖNIG, N. 1986. Verbessertes Druckaufschlu/3system für biologische und anorganische Materialien. Zeitschrift für Pflanzenernährung und Bodenkunde 149:350-353.

HEMP, A. 2002. Ecology of the pteridophytes on the southern slopes of Mt. Kilimanjaro - I. Altitudinal distribution. Plant Ecology 159:211239.

HEMP, A. \& BECK, E. 2001. Erica excelsa as a fire-tolerating component of Mt. Kilimanjaro's forests. Phytocoenologia 31:449-475.

HEMP, A., HEMP, C. \& WINTER, J. C. 1999. Der Kilimanjaro Lebensräume zwischen tropischer Hitze und Gletschereis. Natur und Mensch, Jahresmitteilungen der Naturhistorischen Gesellschaft e.V. 1998:5-28.

HÖLSCHER, D., KÖHLER, L., LEUSCHNER, C. \& KAPPELLE, M. 2003. Nutrient fluxes in stemflow and throughfall in three successional stages of an upper montane rain forest in Costa Rica. Journal of Tropical Ecology 19:557-565.

ISEKI, A., INOUE, T. \& ARAAE, M. 1981. Pedogenesis in a semi-arid zone - a case study of soil genesis in Kilimanjaro, Tanzania. Japanese Journal of Science Soil and Manure 52:230-238.

LILIENFEIN, J., WILCKE, W., AYARZA, M. A., VILELA, L., LIMA, S. C. \& ZECH, W. 2000. Soil acidification in Pinus caribaea forests on Brazilian savanna oxisols. Forest Ecology and Management 128:145-157. 
LIU, W., FOX, J. E. D. \& XU, Z. 2002. Nutrient fluxes in bulk precipitation, throughfall and stemflow in montane subtropical moist forest on Ailao Mountains in Yunnan, south-west China. Journal of Tropical Ecology 18:527-548.

LOVETT, J. C. \& URONU, L. O. N., 1994. Draft field guide to the forest trees of Kilimanjaro. Botanical Museum, Copenhagen, Denmark. 63 pp.

LUNDGREN, B. 1978. Soil conditions and nutrient cycling under natural and plantation forests in Tanzanian Highlands. Reports in Forest Ecology and Forest Soils 31:261.

LUNDGREN, L. \& LUNDGREN, B. 1979. Rainfall, interception and evaporation in the Mazumbai forest reserve, West Usambara Mts., Tanzania and their importance in the assessment of land potential. Geografiska Annaler 61:157-178.

MARO, R. S., CHAMSHAMA, S. A. O., NSOLOMO, V. R. \& MALIONDO, S. M. 1991. Soil chemical characteristics in a natural forest and a Cupressus lusitanica plantation at West Kilimanjaro, Northern Tanzania. Journal of Tropical Forest Science 5:450-464.

MARQUES, R., RANGER, J., GELHAYE, D., POLLIER, B., PONETTE, Q. \& GOEDERT, O. 1996. Comparison of chemical composition of soil solutions collected by zero-tension plate lysimeters with those from ceramic-cup lysimeters in a forested soil. European Journal of Soil Science 47:407-417.

MARRS, R. H., PROCTOR, J., HEANEY, A. \& MOUNTFORD, M. D. 1988. Changes in soil nitrogen-mineralization and nitrification along an altitudinal transect in tropical rain forest in Costa Rica. Journal of Ecology 76:466-482.

McDOWELL, W. H. 1998. Internal nutrient fluxes in a Puerto Rican rain forest. Journal of Tropical Ecology 14:521-536.

MIZOTA, C., KAWASAKI, I. \& WAKATSUKI, T. 1988. Clay mineralogy and chemistry of seven pedons formed in volcanic ash, Tanzania. Geoderma 43:131-141.

MYERS, N., MITTERMEIER, R. A., MITTERMEIER, C. G., DA FONSECA, G. A. B. \& KENT, J. 2000. Biodiversity hotspots for conservation priorities. Nature 403:853-858.

NADKARNI, N. M., SCHAEFER, D., MATELSON, T. J. \& SOLANO, R. 2002. Comparison of arboreal and terrestrial soil characteristics in a lower montane forest, Monteverde, Costa Rica. Pedobiologia 46:2433.

PÓCS, T. 1991. The significance of lower plants in the conservation of Mount Kilimanjaro. Pp. 21-31 in Newmark, W. D. (ed.). The conservation of Mount Kilimanjaro. IUCN, Gland.

PROSPERO, J. M. 1999. Long-range transport of mineral dust in the global atmosphere: impact of African dust on the environment of the southeastern United States. Proceedings of the National Academy of Science of the USA 96:3396-3403.

RØHR, P. C. \& KILLINGTVEIT, A. 2003. Rainfall distribution on the slopes of Mt. Kilimanjaro. Hydrological Science - Journal des Sciences Hydrologiques 48:65-77.

SARMETT, J. D. \& FARAJI, S. A. 1991. The hydrology of Mount Kilimanjaro: an examination of dry season runoff and possible factors leading to its decrease. Pp. 53-70 in Newmark, W. D. (ed.). The conservation of Mount Kilimanjaro. IUCN, Gland.

SCHWERTMANN, U. 1964. Differenzierung der Eisenoxide des Bodens durch Extraktion mit Ammoniumoxalat-Lösung. Zeitschrift für Pflanzenernährung, Düngung und Bodenkunde 105:194-202.

STEINHARDT, U. 1979. Untersuchungen über den Wasser- und Nährstoffhaushalt eines andinen Wolkenwaldes in Venezuela. Göttinger Bodenkundliche Berichte 56:1-182.

TANNER, E. V. J., VITOUSEK, P. M. \& CUEVAS, E. 1998. Experimental investigation of nutrient limitation of forest growth on wet tropical mountains. Ecology 79:10-22.

TRÜBY, P. \& ALDINGER, E. 1989. Eine Methode zur Bestimmung der austauschbaren Kationen im Boden. Zeitschrift für Pflanzenernährung und Bodenkunde 152:301-306.

TUKEY, H. B. 1970. The leaching of substances from plants. Annual Review of Plant Physiology 21:305-322.

VENEKLAAS, E. J. 1990. Nutrient fluxes in bulk precipitation and throughfall in two montane tropical rain forests, Colombia. Journal of Ecology 78:974-992.

VITOUSEK, P. M. 1984. Litterfall, nutrient cycling, and nutrient limitation in tropical forests. Ecology 65:285-298.

WAKATSUKI, T. \& MIZOTA, C. 1992. Salt accumulation in topsoils of irrigated maize fields in comparison with irrigated rice fields in Kilimanjaro region, semiarid Tanzania. Japanese Journal of Soil Science and Plant Nutrition 38:355-358.

WATERLOO, M. J., SCHELLEKEN, J., BRUIJNZEEL, L. A., VUGTS, H. F., ASSENBERG, P. N. \& RAWAQA, T. T. 1997. Chemistry of bulk precipitation in southwestern Viti Levu, Fiji. Journal of Tropical Ecology 13:427-447.

WILCKE, W., YASIN, S., VALAREZO, C. \& ZECH, W. 2001. Change in water quality during the passage through a tropical montane rain forest in Ecuador. Biogeochemistry 55:45-75.

WILCKE, W., YASIN, S., ABRAMOWSKI, U., VALAREZO, C. \& ZECH, W. 2002. Nutrient storage and turnover in organic layers under tropical montane rain forest in Ecuador. Europe an Journal of Soil Science $53: 15-27$. 